\title{
Developing Framework for the Implementation of Advanced Manufacturing Technologies in Small and Medium-Sized Enterprises
}

\author{
Dattatraya V. Bhise \\ Dronacharya Group of Institutions \\ Vivek K. Sunnapwar \\ Lokmanya Tilak College of Engineering
}

\begin{abstract}
Intense competition, demanding customers, and shortening product life cycles are prompting small and medium-sized enterprises to invest in advanced manufacturing technologies (AMTs). Small manufacturers often depend on large manufacturers for orders and so require design as well as manufacturing flexibility on their part. One way of achieving the flexibility is through adoption of AMTs. The decision to invest in AMT is a major decision and thus requires proper consideration to all the aspects of the implementation process before a final commitment is made. Although the technical capabilities of AMTs are well proven, neither practitioner nor academics agree upon a framework for its successful implementation. Using Churchill's model (Steps 1 and 2) and drawing a link from the available literature, a theoretical framework is developed for the successful implementation of AMTs in small and medium-sized enterprises. Three implementation phases-namely, planning,

preimplementation, and postimplementation-with 14 major issues have been developed; 52 constituent factors have been identified from these issues through literature review and interviews with industry professionals.
\end{abstract}

Keywords: implementation, advanced manufacturing technologies, small and medium- sized enterprises, factors

\section{Introduction}

Small and medium-sized enterprises (SMEs) in India are flourishing against a challenging global environment and have experienced several highs and lows in the past few years. In view of the contribution to Indian Gross Domestic Product and its employment generation capability, impetus is being given to strengthen this sector. SMEs occupy an important position in India's economic development and covers variety of industrial sectors as reported by Dangayach and Deshmukh (2005). According to $\mathrm{Li} \mathrm{(2000)} \mathrm{to} \mathrm{respond} \mathrm{quickly} \mathrm{to} \mathrm{market} \mathrm{opportunities} \mathrm{and} \mathrm{threats} \mathrm{firms} \mathrm{must}$ compete simultaneously on variety of competitive priorities. Karan, Forker, and Kobu (2000) pointed that because SMEs are often suppliers of goods and services to larger organizations, they must remain competitive and produce high quality output to meet the quality criteria set by these larger organizations.

To remain competitive, SMEs are introducing newer technologies in products, in manufacturing processes, and in operational control and are investing in advanced manufacturing technologies (AMTs). But these SMEs are facing challenges from internal and external factors while 
implementing newer technologies. SMEs are either not able to adopt new capital intensive technologies or are unable to reap full potential benefits of the AMT implementation due to the lack of resources (Franquesa \& Brandyberry, 2009; Koc \& Bozdag, 2009;Thomas \& Barton, 2012). Studies by Bulbul, Omurbek, Paksoy, and Bektas (2013) and Koc and Bozdag (2009) observed conflicting results from AMT adoption. Although some reported positive results, others reported negative results. For example, when comparing results of implementation from two countries, Sweden and Singapore, Zhou et al. (2009) found that AMT investment was correlated with firm performance in Sweden but not in Singapore.

In wake of this, the selection and implementation of AMT has become a major decision because the survival of small enterprises depends on it. The selection and implementation of an appropriate technology for a firm has to be in line with organizational design and external market requirements, as pointed by Cardoso, Pinheiro de Lima, and Gouvea da Costa (2012).

The technical capabilities of AMT are well proven, so the failure to achieve the intended benefit may be the result of improper and inadequate planning on the part of the organization (Boer \& During 1987; Hayes \& Jaikumar, 1991; Voss, 1988). Boer and During (1987) suggested that issues in both preimplementation and implementation phase are important and have a direct impact on the performance of AMT implementation process. Therefore, firms must pay attention to these issues before implementing AMT projects. However, the information currently available on important factors for AMT implementation in Indian SMEs is not comprehensive but is available in segmented form; therefore, this study is conducted to identify the factors that are effective in the successful implementation of AMT.

In prior studies, Sambasivarao and Deshmukh (1995) suggested tangible, intangible, social, strategic, and technology selection factors; Thomas and Barton (2012) suggested technical and manufacturing support structure factors, and Rahardjo and Yahya (2010) suggested factors like inadequate planning, worker training, top management commitment, and the lack of long-term planning for successful AMT implementation. Although past research has attempted to address the AMT selection and implementation process, it remains inadequate to develop a comprehensive framework that addresses all aspects of the successful AMT implementation in SMEs. In the present study, using Churchill's (1979) paradigm (Figure 1) and a thorough synthesis of the literature, 14 domains of construct of AMT have been developed. For these constructs, 52 constituent factors have been identified through literature review and in-depth interviews with the industry professionals. So this fulfills the requirement of Churchill's paradigm toward the first step of domain of construct for AMT.

\section{Advanced Manufacturing Technologies (AMTs): An Overview}

AMTs are computer-based technologies that respond quickly to design and manufacturing changes. Dean, Yoon, and Susman (1992) and Zammuto and O'Connor (1992) viewed AMT as a potential technology that addresses almost all manufacturing challenges. Three basic categories of AMTs are used by industries: technologies for design/engineering, technologies for manufacturing, and administrative technologies that can be used for planning and control activities. Uwizeyemungu, Poba-Nzaou, and St-Pierre (2015) classified 20 different types of AMT grouped into four categories: design technologies, process technologies, technologies for logistic applications, and communication applications.

Vinas, Bessant, Perez, and Gonzales (2001) and Singh, Garg, and Deshmukh (2006) remarked that SMEs can sustain their growth and competitiveness by adopting AMTs. According to Mosey (2005), 
AMTs can help SMEs in competing with their larger counterparts by developing innovative products. Computer integrated manufacturing helps SMEs to reduce lead time, increase flexibility and reliability, and to improve customer service (Gunasekaran et al. 2001; Dangayach \& Deshmukh 2005). Previous studies have found that AMT has got the potential to accelerate the growth of SMEs. If implemented with proper planning at all levels, these technologies can prove to be a boon for SMEs.

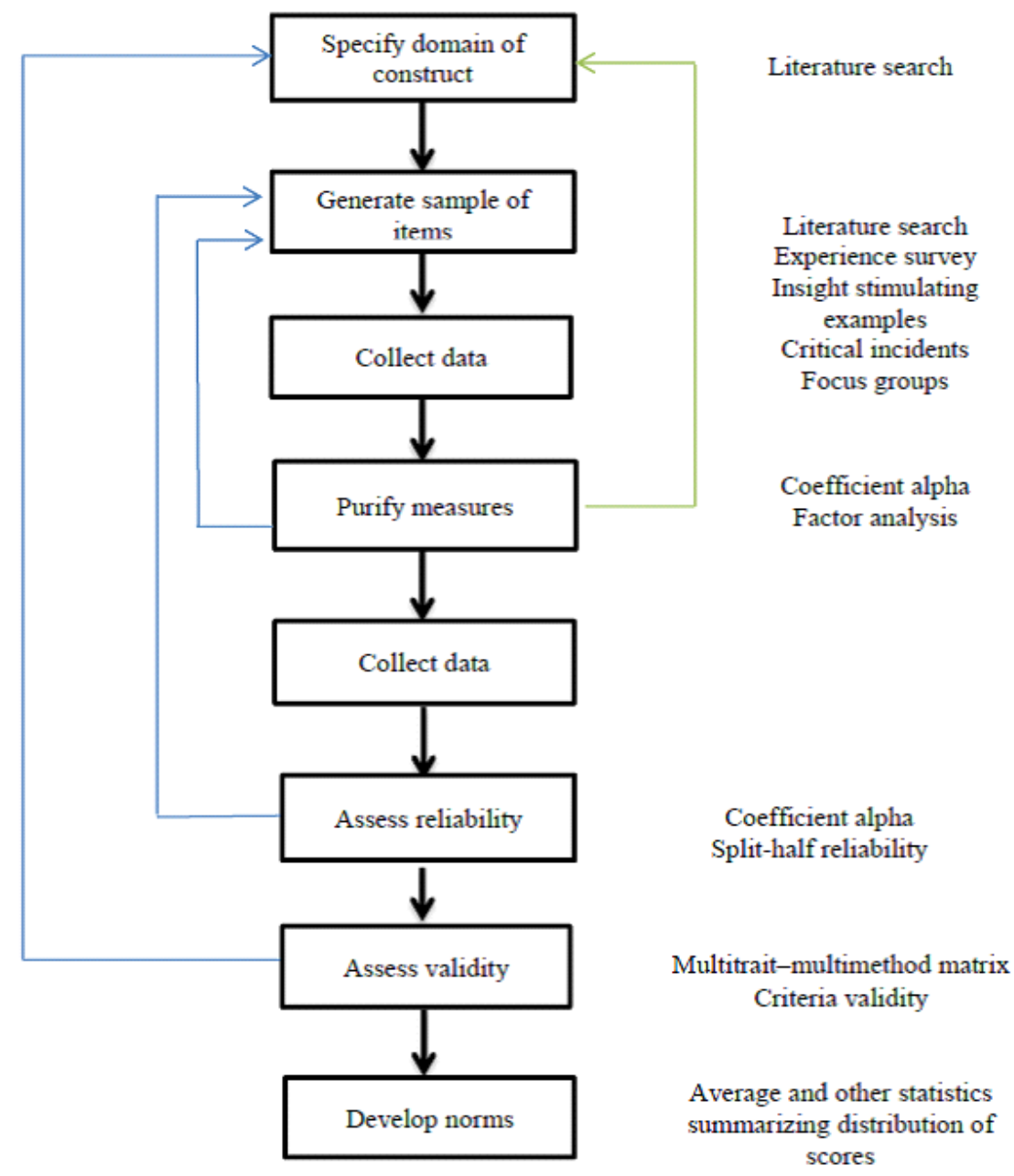

Figure 1. Churchill's Paradigm (adapted from Churchill, 1979) 


\section{Implementation Framework for AMT}

After studying the currently available literature, the framework for implementation of AMT has been developed and is shown in Figure 2.

Implementation of AMT

\begin{tabular}{|c|c|c|}
\hline Planning \& Justification Phase & Preimplementation Phase & Postimplementation Phase \\
\hline 1. Strategic issues & $\begin{array}{l}\text { 1. Organizational changes and } \\
\text { external consultants }\end{array}$ & 1. Manufacturing support \\
\hline \multirow[t]{4}{*}{$\begin{array}{l}\text { 2. Technology selection and } \\
\text { transfer }\end{array}$} & $\begin{array}{l}\text { 2. Continuing management and } \\
\text { manufacturing support }\end{array}$ & $\begin{array}{l}\text { 2. Hands-on training after } \\
\text { installation }\end{array}$ \\
\hline & 3. Human factors & 3. Monitoring \\
\hline & $\begin{array}{l}\text { 4. Vendor selection, participation } \\
\text { and continuity }\end{array}$ & 4. Performance measurement \\
\hline & 5. Implementation practice & \\
\hline
\end{tabular}

Figure 2. Advanced Manufacturing Technologies (AMT) Implementation Framework

\section{The Planning and Justification Phase}

This phase comprises all such decisions that have strategic implications on the business. This viewpoint accepts that every technology decision should have a strategic impact on the business. The need for technological innovations in production processes should be initiated as a result of changing strategic or business objectives that require an evaluation of current production processes. The three main elements of AMT are preimplementation, implementation and postimplementation, which ensure successful implementation of AMT in SMEs. Preimplementation involves predicting the percentage of the probability of implementation success, selecting technologies, and selecting the suppliers of the technology (Dawal et al., 2015).

Yusuff, Yee, and Hashmi (2001) and Soh and Roberts (2005) remarked that many factors need careful consideration to achieve full benefits of AMT implementation. Managers seeking AMT adoption in their organizations must match products with technologies that offer not only operational benefits but also marketing and strategic advantages (Chen \& Small, 1994). Mamalis (2005) pointed that thorough consideration has to be given when selecting the appropriate technology that matches with the objective of the organization. This means the firm has to manage the complete supply chain through collaboration and partnerships with customers, vendors, distributors, competitors, consulting firms, or research centers. Monge, Rao, Gonzalez, and Sohal (2006) highlighted that investment in AMT is a long and complex process that requires long periods of planning, and the outcome may not be immediately visible. Selection of appropriate technology 
that meets organizations' objectives and fulfills plants' requirement should be done, and the selected technology must be economically justifiable. Strategic and technology selection factors are identified as being critical to success during this phase and are shown in Appendix A.

\section{The Preimplementation Phase}

Organizational culture and changes, decisions on external consultants, continuous management support, vendor selection, and human and social factors are some the prominent preimplementation issues that an organization has to sort out. AMTs and organizational performance have a complex relationship, as reported by Koc and Bozdag (2009). This complex relationship is attributed to internal as well as external factors, remarked Koellinger (2008). According to Saberi, Yusuff, Zulkifli, and Megat Ahmad (2010), AMT failure is often a result of an adequate implementation and diffusion of the new innovation through the organization. Studies by Saberi et al. (2010), Darbanhosseiniam (2012), and Marri, Gunasekaran, and Sohag (2007) emphasized the importance of strategic and organizational factors in effective AMT implementation. Cardoso et al. (2012) highlighted that most of the problems arise due to lack of proper analysis and identification of organizational characteristics.

\section{The Postimplementation Phase}

This phase addresses all the activities that should be performed after the installation and productive operation of the technology within the manufacturing environment. The available literature reveals that companies that pay attention to the areas listed in Appendix A are more likely to experience success than their counterparts.

\section{Identification of Constituent Factors}

The second step of Churchill's paradigm (Figure 1) is conducting a literature search and interview with industry professionals to generate constituent factors for AMT implementation framework. As part of this, an extensive literature review was performed to identifying constituent factors associated with AMT. Sambasivarao and Deshmukh (1995) have identified factors like tangible and intangible, which are further classified into preproduction cost factors, indirect production cost, direct production cost, human, strategic, social, and technological factors. From a review of literature and face-to-face interviews with industry professionals, 63 constituent factors associated with the 14 AMT are identified. These items should possess content validity. As advocated by Churchill (1979), the study requested a group consisting of four academicians and four practitioners to evaluate these factors. Each member initially assessed the items independently and then jointly discussed the items in dispute and finally come to a consensus. Using the nominal grouping technique, they established 52 constituent factors relevant to AMT implementation framework. These items, along with their literature relevance, are shown in Appendix B.

\section{Concluding Remarks}

The main focus of this article has been on developing the framework and identifying major issues and their constituent factors for the implementation of AMTs in SMEs. According to Churchill's (1979) model, the domain of construct has to be identified first, and so from three implementation phases, 14 major issues have been identified and addressed. This satisfies the first step in the paradigm of Churchill. The second step of paradigm involves conducting a literature search and interviews of industry professionals to generate constituent factors for the major issues. Thus, 52 constituent factors have been identified from 14 major issues of the implementation process. In next 
stage of Churchill's model, these factors can be advanced for validation and generalization. The proposed framework including constituent factors seems to be exhaustive and can be put for empirical investigation further. This study has implications for the managers of SMEs who seek to introduce AMT in their plants.

\section{References}

Adler, P. S. (1986). New technologies, new skills. California Management Review, 29, 9-28.

Adler, P. S. (1988). Managing flexible automation. California Management Review, 30, 34-56.

Amoako-Gyampah, K., \& Maffei, M. J. (1989). The adoption of flexible manufacturing systems: Strategic considerations, Technovation, 9, 479-491.

Anderson, J. C., Cleveland, G., \& Schroeder, R. G. (1989). Operations strategy: A literature review, Journal of Operations Management, 8, 133-158.

Attaran, M. (1989a). Strategic s in the automated factory. Industrial Management Data Systems, 4, $14-19$.

Attaran, M. (1989b). The automated factory: Justification and implementation, Business Horizons, $32,80-85$.

Attaran, M. (1992). Flexible manufacturing systems: Implementing an automated factory. Information Systems Management, 9, 44-47.

Beatty, C. A. (1990). Implementation of advanced manufacturing technology. Business Quarterly, 55, $46-50$.

Beatty, C. A. (1993). Critical implementation decisions for advanced manufacturing technologies, International Journal of technology Management, 8,189-196.

Beatty, C. A., \& Gordon, J. R. M. (1988). Barriers to the implementation of CAD/CAM systems, Sloan Management Review, 29, 25-34.

Beatty, C. A., \& Gordon, J. R. M. (1990). Advanced manufacturing technology: Making it happen. Business Quarterly, 54, 46-53.

Bessant, J., \& Heyward, B. (1986). Flexibility in manufacturing systems, Omega, 14, 465-473.

Bessant, J. (1991). Managing advanced manufacturing technology: The challenge of the fifth wave. Manchester, United Kingdom: Blackwell.

Bessant, J., \& Haywood, B. (1988). Flexible manufacturing in Europe. European Management Journal, 6, 139-142.

Billesbach, T. J. (1991). A study of the implementation of just-in-time in the United States. Production and Inventory Management Journal, 32, 1-4.

Bititci, U. (1994). Measuring your way to profit. Management Decision, 32, 6.

Bititci, U. (1995). Measuring the integrity of your business. Management Decision, 33, 7.

Bititci, U., Carrie, A., \& McDevitt, L. (1997). Integrated performance measurement systems: A development guide. International Journal of Operations \& Production Management, 17, 5.

Bititci, U., Carrie, A., \& Turner, T. (1998). Diagnosing the integrity of your performance measurement system. Control Magazine, April, 9-13. 
Bititci, U., Suwignjo, P., \& Carrie, A. S. (2001). Strategy management through quantitative modelling of performance measurement systems. International Journal of Production Economics, 69, 15-22.

Blois, K. J. (1986). Marketing strategies and the new manufacturing technologies. International Journal of Operations and Production Management, 6, 34-41.

Blois, K. J. (1991). Trends in marketing and their implication for manufacturing. International Journal of Technology Management, 6, 385-394.

Boer, H., \& During, W. E. (1987). Management of process innovation: The case of FMS: A systems approach. International Journal of Production Research, 25, 1671-1682.

Boer, H., Hill, M., \& Krabbendam, K. (1990). FMS implementation management: Promise and performance. International Journal of Operations \& Production Management, 10, 5-20.

Booz Allen Hamilton, Inc. (1982, November). Manufacturing strategy: Concepts and application. New York, NY: Author.

Boyer, K. (1998). Longitudinal linkages between intended and realized operations strategies, International Journal of Operations and Production Management, 18, 356-373.

Boyer, K. K. (1999). Eutionary patterns of flexible automation and performance: A longitudinal study. Management Science, 45, 824-842.

Boyer, K. K., Leong, G., Ward, P. T., \& Krajewski, L. (1997). Unlocking the potential of advanced manufacturing technologies. Journal of operations Management, 15, 331-347.

Boyer, K. K., \& McDermott, C. (1999). Strategic consensus in operations strategy, Journal of Operations Management, 17, 289-305.

Boyer, K. K., Ward, P. T., \& Leong, G. K. (1996). Approaches to the factory of the future: An empirical taxonomy. Journal of Operations Management, 14, 297-313.

Brown, D. M., \& Laverick, S. (1994). Measuring corporate performance. Long Range Planning, 27, $89-98$.

Buffa, E. S. (1980). Research in operations management, Journal of Operations Management, 1, 1-8.

Bulbul, H., Omurbek, N., Paksoy, T., \& Bektas, T. (2013). An empirical investigation of advanced manufacturing technology investment patterns: Evidence from a developing country. Journal of Engineering and Technology Management, 30, 136-156.

Cagliano, R., \& Spina, G. (2000). Advanced manufacturing technologies and strategically flexible production. Journal of Operations Management, 18, 169-190.

Cardoso, R. D. R., Pinheiro de Lima, E., \& Gouvea da Costa, S. E. (2012). Identifying organizational requirements for the implementation of advanced manufacturing technologies (AMT). Journal of Manufacturing Systems, 31, 367-378.

Carlson, C. K., Gardner, E. P., \& Ruth, S. R. (1989). Technology-driven long-range planning, Journal of Information Systems Management, 6, 24-29.

Chang, D., \& Lee, S. M. (1996). Impact of critical success factors for JIT implementation on organizational performance. Production Planning and Control, 7, 329-338.

Chang, K. B. (1991). Deriving advantages from advanced manufacturing technology: An organizing paradigm. International Journal of Production Economics, 25, 13-21.

Chen, I. J., \& Small, M. H. (1994). Implementing advanced manufacturing technology: An integrated planning model. Omega, 22, 91-103. 
Chen, I. J., \& Small, M. H. (1996). Planning for advanced manufacturing technology. International Journal of Operations and Production Management, 16, 4-25.

Cleland, D. I., Bidanda, B., \& Chung, C. A. (1995). Humans in technology implementation. Industrial Management, 37, 4, 22-26.

Cleland, D. I., \& Bursic, K. M. (1992). Strategic technology management: Systems for products and processes. New York, NY: AMACOM.

Cleveland, G. (1986). Manufacturing competence: The link between production systems and business strategy (Doctoral thesis). School of Management, University of Minnesota, Minneapolis, MN.

Co, H., \& Flowers, D. (1990). A case study on computer integrated manufacturing, Manufacturing Review, 2, 2.

Cohen, M. A., \& Apte, U. M. (1997). Manufacturing automation. Chicago, IL: Irwin.

Collins, P., Hage, J., \& Hull, F. M. (1988). Organizational and technological predictors of change in automacity. Academy of Management Journal, 31, 512-543.

Corbett, C., \& Van Wassenhove, L. (1993). Trade-offs? What trade-offs? Competence and competitiveness in manufacturing strategy. California Management Review, 35, 107-122.

Curtis, D. A. (1987). An heuristic to evaluate investments for improved economies of scope in manufacturing. Journal of Manufacturing Systems, 6, 325-327.

Dangayach, G. S., \& Deshmukh, S. G. (2005). Advanced manufacturing technology implementation evidence from Indian small and medium enterprises (SMEs). Journal of Manufacturing Technology Management, 16, 483-496.

Darbanhosseiniamirkhiz, W. I. (2012). Advanced manufacturing technology adoption in SMEs, Journal of Technology Management and Innovation, 7, 112-120,

Dawal, S. Z., Tahriri, F., Jen, Y. H., Case, K., Tho, N. H., Zuhdi, A., . . Sakundarini, N. (2015). Empirical evidence of AMT practices and sustainable environmental initiatives in Malaysian Automotive SMEs. International Journal of Precision Engineering and Manufacturing, 16, $1195-1203$.

De Meyer, A., \& Ferdows, K. (1990). Influence of manufacturing improvement programs on performance. International Journal of Operations \& Production Management, 10, 120-31.

Dean J. W., Yoon, S. J., \& Susman, G. I. (1992). Advanced manufacturing technology and organization structure: Empowerment or subordination? Organization Science, 3, 203-229.

Dean Jr., J. W., \& Snell, S. A. (1991). Integrated manufacturing and job design: An empirical examination. Strategic Management Journal, 34, 776-804.

Dean Jr., J. W., \& Snell, S. A. (1996). The strategic use of integrated manufacturing: An empirical examination. Strategic Management Journal, 17, 459-480.

Demmel, J. G., \& Askin, R. G. (1992). A multiple-objective decision model for the evaluation of advanced manufacturing system technologies. Journal of Manufacturing System, 11, 179194.

Diaz, M. S, Machuca, J. A. D., \& Alvarez-Gil, M. J. (2003). A view of developing patterns of investment in AMT through empirical taxonomies: new evidence. Journal of Operations Management, 21, 577-606.

Doll, J. W., \& Vonderembse, M. A. (1987). Forging a partnership to achieve competitive advantage: The CIM challenge. MIS Quarterly, 10, 205-220. 
Dornan, S. B. (1987). Cells and systems: Justifying the investment. Production, 99, 30-35.

Efstathiades, A., Tassou, S., \& Antoniou, A. (2002). Strategic planning, transfer and implementation of Advanced Manufacturing Technologies (AMT): Development of an integrated process plan. Technovation, 22, 201-212.

Ettlie, J. E. (1990). What makes a manufacturing firm innovative? Academic Management Executive, 4, 7-20.

Ettlie, J. E., \& Reza, E. M. (1992). Organizational integration and process innovation. Academy of Management Journal, 35, 795-827.

Falkner, C. H., \& Benhajla, S. (1990). Multi-attribute decision models in the justification of CIM systems. The Engineering Economist, 35, 91-114.

Farley, J. U., Kahn, B., Lehman, D. R., \& Moore, W. L. (1987). Modeling the choice to automate, Sloan Management Review, 5, 5-15.

Ferdows, K., Miller, J. G., Nakane, J., \& Voilmann, T. E. (1986). Evolving global manufacturing strategies: Projections into the 1990s. International Journal of Operations \& Production Management, 6, 6-16.

Ferraro, R. A. Hunley, T. E., \& Shackney, O. Y. (1988). Banishing management barriers to automation. Manufacturing Engineering, 100, 44-48.

Finnie, J. (1988). The role of financial appraisal in decisions to acquire advanced manufacturing. Accounting and Business Research, 18, 133-139.

Franquesa, J., \& Brandyberry, A. (2009). Organizational slack and information technology innovation adoption in SMEs. International Journal of E-Business Research, 5, 25-48.

Fry, T. D., \& Smith, A. E. (1989). FMS implementation procedure: A case study. IIE Transactions on Industrial Engineering, 21, 288-293.

Gerwin, D. (1988). A theory of innovation processes for computer aided manufacturing technology, IEEE Transactions on Engineering Management, 35, 90-100

Gerwin, D. (1993). Manufacturing flexibility: A strategic perspective. Management Science, 39, 395410.

Ghalayini, A. M., \& Noble, J. S. (1996). The changing basis of performance measurement, International Journal of Operations \& Production Management, 16, 63-80.

Ghosh, B. K., \& Wabalickis, R. N. (1991). A comparative analysis for the justification of future manufacturing systems. International Journal of Operations \& Production Management, 11, $4-23$.

Goldhar, J. D., Jelinik, M., 7 Schlie, T. W. (1991). Competitive advantage in manufacturing through information technology. International Journal of Technology Management, 6, 162-180.

Green, S., Gavin, M., \& Aiman-Smith, L. (1995). Assessing a multidimensional measure of radical technological innovation. IEEE Transactions on Engineering Management, 42, 203-214.

Gunasekaran, A., Patel, C., \& Tirtiroglu, E. (2001). Performance measures and metrics in a supply chain environment. International Journal of Operations \& Production Management, 21, 7187.

Gupta, Y. P. (1988). Organizationals of flexible manufacturing systems. Technovation, 8, 255-268.

Gupta, Y. P., \& Somers, T. M. (1993). Factory automation and integration of business functions. Journal of Manufacturing Systems, 12, 15-23. 
Haskins, R., \& Petitt, T. (1988). Strategies for entrepreneurial manufacturing. Journal of Business Strategy, 9, 42-50.

Hayes, R. H., \& Jaikumar, R. (1991). Requirements for successful implementation of new manufacturing technologies. Journal of Engineering and Technology Management, 7, 169-75.

Hayes, R. H., Wheelwright, S. C., \& Clark, K. B. (1988). Dynamic manufacturing: Creating the learning organization. New York, NY: Free Press.

Hershfield, D. (1992). Proceed one step at a time to implement automation effectively. Industrial Engineering, June, 22-26.

Hitt, M., Hoskisson, R. E., \& Nixon, R. D. (1993). A mid-range theory of inter-functional integration: Its antecedents and outcomes. Journal of Engineering and Technology Management, 10, 161185.

Hottenstein, M. P., Casey, M. S., \& Dunn, S. C. (1997). Facilitation of advanced manufacturing technology: Implementation and transfer. Industrial Management, 39, 8-12.

Jaikumar, R. (1986). Post-industrial manufacturing. Harvard Business Review, 66, 69-76.

Jonsson, P. (2000). An empirical taxonomy of advanced manufacturing technology. International Journal of Operations and Production Management, 20, 1446-1474.

Kahn, K. B. (1996). Interdepartmental integration: A definition with implications for product development performance. Journal of Product Innovation Management, 13, 137-151.

Kakati, M., \& Dhar, U. R. (1991). Investment justification in flexible manufacturing systems. Engineering Costs and Production Economics, 21, 203-209.

Kaplan, R. S., \& Norton, D. P. (1992). The balanced scorecard measures that drive performance. Harvard Business Review, 70, 71-9.

Karan, A., Forker, L., \& Kobu, B. (2000). Improving operations performance in a small company: A case study. International Journal of Operations \& Production Management, 20, 316-335.

Karsak, E., \& Tolga, E. (2001). Fuzzy multi-criteria decision-making procedure for evaluating advanced manufacturing system investments. International Journal of Production Economics, 69, 49-64.

Kim, Y., \& Lee, J. (1993). Manufacturing strategy and production systems: An integrated framework. Journal of Operations Management, 11, 3-15.

Koc, T., \& Bozdag, E. (2009). The impact of AMT practices on firm performance in manufacturing SMEs. Robotics and Computer-Integrated Manufacturing, 25, 303-313.

Koellinger, P. (2008). The relationship between technology, innovation, and firm performance: Empirical evidence from e-business in Europe. Research Policy, 37, 1317-1328.

Kotha, S., \& Swamidass, P. M. (2000). Strategy, advanced manufacturing technology and performance: Empirical evidence from U.S. manufacturing firms. Journal of Operations Management, 18, 257-277.

Lefley, F., Wharton, F., Hajek, L., Hynek, J. \& Janecek, V. (2004). Manufacturing investments in the Czech Republic: An international comparison. International Journal of Production Economics. 1, 1-14.

Lewis, M. W. (1998). Iterative triangulation: a theory development process using existing case studies. Journal of Operations Management, 16, 455-469. 
Lewis, M. W., \& Boyer, K. K. (2002). Factors impacting AMT implementation: An integrative and controlled study. Journal of Engineering and Technology Management, 19, 111-130.

Li, L. X. (2000). An analysis of sources of competitiveness and performance of Chinese manufacturers. International Journal of Operations \& Production Management, 20, 219-315.

Lin, C. Y., \& Chen, W. (2000). The effect of social factors on the implementation of automation: An empirical study in Taiwan. Journal of Engineering Technology Management, 17, 39-58.

Lowe, J. (1993). The diffusion of a manufacturing innovation: The case of JIT and MRP. International Journal of Technology Management, 3, 244-258.

MacDougall, S. L., \& Pike, R. H. (2003). Consider your options: Changes to strategic value during implementation of advanced manufacturing technology. OMEGA: The International Journal of Management Science, 31, 1-15.

Mamalis, A. G. (2005). Advanced manufacturing engineering. Journal of Materials Processing Technology, 161, 1-9.

Marri, H., Gunasekaran, A., \& Sohag, R. (2007). Implementation of advanced manufacturing technology in Pakistani small and medium enterprises: An empirical analysis. Journal of Enterprise Information Management, 20, 726-739.

Martin, T. (1990). The need for human skills in production: The case of CIM. Computers in Industry, 14, 205-211.

McDermott, C. M., \& Stock, G. N. (1999). Organizational culture and advanced manufacturing technology implementation. Journal of Operations Management, 17, 521-533

McDonough, E. F., \& Barczak, G. (1992). 'The effects of cognitive problem- solving orientation and technological familiarity on faster new product development. The Journal of Product Innovation Management, 9, 44-52.

McDougall, D. C. (1986). Manufacturing strategy in diversified forms: Linkages between competitive strategy and manufacturing planning in the divisions (Doctoral thesis). Harvard University, Cambridge, MA.

Meredith J. R. (1987a). Implementing new manufacturing technologies: managerial lessons over the FMS life-cycle. Interfaces, 17, 51-62.

Meredith, J. R. (1987b). The strategic advantages of new manufacturing technologies for small firms, Strategic Management Journal, 8, 249-258.

Meredith J. R. (1988). The role of manufacturing technology in competitiveness: Peerless laser processes. IEEE Transactions on Engineering Management, 35, 1, 3-10.

Meredith, J. R., \& Hill, M. M. (1987). Justifying new manufacturing systems: A managerial approach. Sloan Management Review, 28, 49-61.

Miller, J. G., \& Roth, A. V. (1994). A taxonomy of manufacturing strategies. Management Science, 40, $285-304$.

Mize, J. H. (1987). Success factors for advanced manufacturing systems. In K. M. Blache (Ed.), success factors for implementing change: A manufacturing viewpoint (pp. 23-27). Dearborn, MI: Society of Manufacturing Engineers.

Mohanty, R. P. (1993). Analysis of justification problems in CIMS: Review and projections. International Journal of Production Planning and Control, 4, 252-273. 
Monge, C. A. M., Rao, S. S., Gonzalez, M. E., \& Sohal, A. S. (2006). Performance measurement of AMT: A cross regional study. Benchmarking, 13, 135-146.

Morgan, L. O., \& Daniels, R. L. (2001). Integrating product mix and technology adoption decisions: A portfolio approach to adoption of advanced manufacturing technologies in the automobile industry. Journal of Operations Management, 19, 219-38.

Mosey, S. (2005). Understanding new to market product development in SMEs. International Journal of Operations \& Production Management, 25, 114-130.

Nemetz, P. L., \& Fry, L. W. (1988). Flexible manufacturing organizations: Implications for strategy formulation and organization. Academy of Management Review, 13, 627-639.

Noori, H. (1990). Managing the dynamics of new technology: Issues in manufacturing management. Englewood Cliffs, NJ: Prentice Hall.

Parthasarthy, R., \& Sethi, S. P. (1992). The impact of flexible automation on business strategy and organizational structure. Academy of Management Review, 17, 86-111.

Parthasarthy, R., \& Sethi, S. P. (1993). Relating strategy and structure to flexible automation: A test of fit and performance implications. Strategic Management Journal, 14, 529-550.

Primrose, P. L. (1991). Investment in manufacturing technology. London, United Kingdom: Chapman and Hall.

Rahardjo, J., \& Yahya , S. (2010). Advanced manufacturing technology implementation. Journal of Technology Management, 12, 101-108.

Ramamurthy, K. (1995). The influence of planning on implementation success of advanced manufacturing technologies. IEEE Transactions on Engineering Management, 42, 62-73.

Ramasesh, R. V., \& Jayakumar, M. D. (1993). Economic justification of advanced manufacturing technology. Omega, 21, 289-306.

Ranta, J., \& Tchijov, I. (1990). Economics and success factors of flexible manufacturing systems: The conventional explanation revisited. International Journal of Flexible Manufacturing Systems, $2,169-190$.

Roth, A. V., Gaimon, C., \& Krajewski, L. (1991). Optimal acquisition of FMS technology subject to technological progress, Decision Sciences, 22, 308-334.

Roth, A. V., \& Miller, J. G. (1992). Success factors in manufacturing. Business Horizons, 35, 73-81.

Rubenowitz, S., Olsson, A., \& Steen, B. (1990). The new roles of management in plants with an advanced CNC-technology. International Journal of Operations and Production Management, 10, 26-36.

Saberi, S., Yusuff, R. M., Zulkifli, N., \& Megat Ahmad, M. M. H. (2010). Effective Factors on Advanced Manufacturing Technology Implementation Performance: A Review, Journal of Applied Sciences, ume 10, 13, 1229-1242

Salaheldin, S. (2007). The impact of organizational characteristics on AMT adoption. Journal of Manufacturing Technology Management. 18, 443-460.

Sambasivarao, K. V., \& Deshmukh, S. G. (1994). Strategic framework for implementing the flexible manufacturing systems in India. International Journal of Operations and Production Management, 14, 52-65. 
Sambasivarao, K. V., \& Deshmukh, S. G. (1995). Selection and implementation of advanced manufacturing technologies. International Journal of Operations \& Production Management, $15,43-62$.

Saraph, J. V., \& Sebastian, R. J. (1992). Human resource strategies for effective introduction of advanced manufacturing technologies. Production and Inventory Management Journal, 33, $64-70$.

Schroder, R., \& Sohal, A.S. (1999). Organizational characteristics associated with AMT adoption: Towards a contingency framework. International Journal of Operations and Production Management, 19, 1270-1291.

Singh, R. K., Garg, S. K., \& Deshmukh, S. G. (2006). Strategy development by Indian SMEs in plastic sector: An empirical study. Singapore Management Review, 28, 65-83.

Singh, H., \& Khamba, J. (2009). An evaluation of AMTs utilisation in Indian industry for enhanced manufacturing performance: Evidence from large- and medium-scale organisations. International Journal of Indian Culture and Business Management, 2, 585-601.

Small, M. H., \& Yasin, M. (1997). Developing a framework for the effective planning and implementation of advanced manufacturing technology. International Journal of Operations \& Production Management, 17, 468-489.

Small, M. H. (1993). Towards successful implementation of advanced manufacturing technology: A process-factors-process approach (Doctoral dissertation). Cleveland State University, Cleveland, $\mathrm{OH}$.

Small, M. H., \& Chen, I. J. (1995). Investment justification of advanced manufacturing technology: An empirical analysis. Journal of Engineering and Technology Management, 12, 27- 55.

Smith, A., Fry, T., Philipoom, P., \& Sweigart, J. (1993). A comparison of two intelligent scheduling systems for flexible manufacturing systems. Expert System With Application, 6, 299-308.

Soh, P. H., \& Roberts, E. B. (2005). Technology alliances and networks: An external link to research capability. IEEE Transactions on Engineering Management, 52, 419-428.

Sohal Amrik, S. (1999). Introducing new technology in to a small business: A case study. Technovation, 19, 187-193.

Sohal, A. (1994). Investing in advanced manufacturing technology: Comparing Australia and the United Kingdom. Benchmarking for Quality Management \& Technology, 1, 24-41.

Sohal, A. (1996). Assessing AMT implementations: An empirical field study. Technovation, 16, 377384.

Sohal, A., Samson, D., \& Weill, P. (1991). Manufacturing and technology strategy: A survey of planning for AMT. Computer Integrated Manufacturing Systems, 4, 71-79.

Sohal, A. S. (1991). Investing in AMT. Australian Accountant, 61, 40-44.

Sohal, A. S., Burcher, P. G., \& Lee, G. (1999). Comparing American and British practices in AMT adoption. Benchmarking, 6, 310-324.

Sohal, A. S., Gordon, J., Fuller, G., \& Simon, A. (1999). Manufacturing practices and competitive capability: An Australian study. Technovation, 19, 295-304.

Somers, T., \& Gupta, Y. P. (1991). Factory automation: U.S. versus Japanese experiences. Manufacturing Review, 3, 157-166. 
Souder, W. E., \& Padmanabhan, V. (1989). Transferring new technologies from R\&D to manufacturing. Research Technology Management, 32, 38-43.

Staughton, R. V. W., Knight, M. A., \& Younger, A. (1998). Assisting small manufacturing firms to implement advanced manufacturing technology. International Journal of Operations \& Production Management, 6, 38-43.

Stecke, K. E. (1985). Design, planning, scheduling, and control problems of flexible manufacturing systems. Journal of Operations Research, 3, 3-25.

Swamidass, P. M. (1987). Planning for manufacturing technology. Long Range Planning, 20, 125133.

Swamidass, P. M., \& Kotha, S. (1998). Explaining manufacturing technology use, firm size and performance using a multidimensional view of technology. Journal of Operations Management, 17, 23-37.

Swamidass, P. M., \& Waller, M. A. (1991). A classification of approaches to planning and justifying new manufacturing technologies. Journal of Manufacturing Systems, 9, 181-193.

Swann, K., \& O'Keefe, W. D. (1990a). Advanced manufacturing technology: Investment decision process, Part I. Management Decision, 28, 20-31.

Swann, K. and O'Keefe, W.D. (1990b). Advanced manufacturing technology: Investment decision process, Part 2. Management Decision, 28, 27-34.

Swink, M., \& Way, M. H. (1995). Manufacturing strategy: Propositions, current research, renewed directions. International Journal of Operations and Production Management, 15, 4-26.

Szwejczewski, M., Mapes, J., \& New, C. (1997). Delivery and trade-offs. International Journal of Production Economics, 53, 323-330.

Taheri, J. (1990). Northern telecom tackles successful implementation of cellular manufacturing. Industrial Engineering, 22, 38-43.

Takanaka, H. (1991). Critical success factors in factory automation. Long Range Planning, 24, 4.

Tchijov, I. (1989). CIM introduction: Some socio-economic aspects. Technological Forecasting and Social Change, 35, 261-275.

Tetzlaff, U. A. W. (1990). Optimal design of flexible manufacturing systems. New York, NY: PhysicaVerlag.

Thomas, A. J., \& Barton, R. A. (2012). Characterizing SME migration towards advanced manufacturing technologies. Proceedings of the Institution of Mechanical Engineers, Part B: Journal of Engineering Manufacture, 226, 745-756.

Tranfield, D., Smith, S., Ley, C., Bessant, J., \& Levy, P. (1991). Changing the orgnisational design and practices for computer-integrated technologies. International Journal Technology Management, 6, 211-221.

Troxler, J. W., \& Blank, I. (1990). Decision support system for value analysis of integrated manufacturing technology. In H. Parsaei, T. Ward, \& W. Karwoski (Eds), Justification methods for integrated manufacturing systems (pp. 193-202). New York, NY, Elsevier.

Udo, G. J., Ehie, I. C., \& Olorunniwo, F. (1995). Fulfilling the promises of advanced manufacturing systems. Industrial Management, 37, 23-8. 
Udoka, S. J., \& Nazemetz, J. W. (1990). An empirically based analysis of the requirements for successful implementation of advanced manufacturing technology (AMT). Computers and Industrial Engineering, 19, 131-135.

Uwizeyemungu, S., Poba-Nzaou, P., \& St-Pierre, J. (2015, May). Assimilation patterns in the use of advanced manufacturing technologies in SMEs: Exploring their effects on product innovation performance. Journal of Information Systems \& Technology Management, 12, 271-288.

Vesey, J. T. (1990). Meet the new competitors: They think in terms of speed-to-market. Industrial Engineering, 22, 20-26.

Vinas, B. C. B., Bessant, J., Perez, G. H., \& Gonzales, A. A. (2001). A conceptual model for the development of technological management processes in manufacturing companies in developing countries. Technovation, 21, 345-352.

Voss C. A. (1986). Managing advanced manufacturing technology. International Journal of Operations and Production Management, 6, 4-7.

Voss C. A. (1988) Implementation: A key in manufacturing technology: The need for a field of study. Research Policy, 17, 51-62.

Voss, C. A. (1995). Manufacturing strategy: The nature of the link between manufacturing strategy and organizational structure. London, United Kingdom: Chapman and Hall.

Wabalickis, R. N. (1988). Justification of FMS with the analytic hierarchy process. Journal of Manufacturing Systems, 7, 175-182.

Ward, P. T., Leong, G. K., \& Boyer, K. K. (1994). Manufacturing proactiveness and performance. Decision Sciences, 25, 337-358.

Ward, P. T., McCreery, J. K., Ritzman, L. P., \& Sharma, D. (1998). Competitive priorities in operations management. Decision Sciences, 29, 1035-1046.

Weatherall, A. (1988). Computer integrated manufacturing. New Delhi, India: Affiliated East-West Press Pvt.

Weill, P., Samson, D. A., \& Sohal, A. S. (1991). Advanced manufacturing technology: An analysis of practice. International Journal of Technology Management , 6, 335-353.

Womack, J. P., Jones, D. R., \& Roos, D. (1991). The machine that changed the world. New York, NY: Harper Perennial.

Young, A. R., \& Murray, J. (1986). Performance evaluation of FMS. International Journal of Operations \& Production Management, 6, 57-62.

Yusuff, R., Chek, L., \& Hashmi, M.(2005). Advanced manufacturing technologies in SMEs. CACCI Journal, 1, 1-11.

Yusuff, R., Megat A., Megat M. \& Osman, M.(2004). Barriers to advanced manufacturing technologies implementation in the small and medium scales industries of a developing country. International Journal of Engineering and Technology. 1, 39-46.

Yusuff, R. M., Yee, K. P., \& Hashmi, M. S. J. (2001). A preliminary study on the potential use of the analytical hierarchical process (AHP) to predict advanced manufacturing technology (AMT) implementation. Robotics and Computer Integrated Manufacturing, 17, 421-427.

Zahra, S. A., \& Covin, J. G. (1993). Business strategy, technology policy and firm performance. Strategic Management Journal, 14, 451-478. 
Zahra B., \& Farzad T. (2010). Justification and classification of issues for the selection and implementation of advanced manufacturing technologies. International Journal of Industrial and Manufacturing Engineering, 4, 410-417.

Zammuto, R. F., \& O'Connor, E. J. (1992). Gaining advanced manufacturing technologies benefits: The roles of organization design and culture. Academy of Management Review, 17, 701-728.

Zhoa, H., \& Co, H. C. (1997). Adoption and implementation of advanced manufacturing technology in Singapore. International Journal of Production Economics, 48, 7-19.

Zhou, H., Leong, G. K., Jonsson, P., \& Sum, C.-C. (2009). A comparative study of advanced manufacturing technology and manufacturing infrastructure investments in Singapore and Sweden, International Journal of Production Economics, 120, 42-53.

[Appendices follow] 


\section{Appendix A}

\section{AMT Implementation Factors Derived From Prior Research}

\begin{tabular}{|c|c|c|}
\hline Number & Factor & Literature Relevance \\
\hline \multicolumn{3}{|c|}{ Planning phase } \\
\hline 1 & Strategic issues & $\begin{array}{l}\text { Boer and During (1987); Voss (1988); Hayes and Jaikumar } \\
\text { (1991); Small and Yasin (1997); Bessant and Haywood (1988); } \\
\text { Anderson et al. (1989); Carlson et al. (1989); Cleland and } \\
\text { Bursic (1992); Parthasarthy and Sethi (1992); Swamidass and } \\
\text { Waller (1991); Chang (1991); Udoka and Nazemetz (1990); } \\
\text { Zahra and Covin (1993); Weill et al. (1991); Lowe (1993); } \\
\text { Corbett and Van-Wassenhove (1993); Diaz (2003); Dangayach } \\
\text { and Deshmukh (2005); Rosnah, Loo, and Hashmi (2005); } \\
\text { Yusuff (2004); Lefley et al (2004); Singh and Khamba (2009) }\end{array}$ \\
\hline 2 & $\begin{array}{l}\text { Technology } \\
\text { selection and } \\
\text { transfer }\end{array}$ & $\begin{array}{l}\text { Boyer and MacDermott (1999); Miller and Roth (1994); Ward et } \\
\text { al. (1998); Beatty and Gordon (1990); Stecke (1985); Tetzlaff } \\
\text { (1990); Hayes and Jaikumar (1991); Parthasarthy and Sethi } \\
\text { (1992); Udoka and Nazemetz (1990); Gupta (1998); Meredith } \\
\text { (1987b); Jonsson (2000); Mamalis (2005) }\end{array}$ \\
\hline \multicolumn{3}{|c|}{ Preimplementation phase } \\
\hline 3 & $\begin{array}{l}\text { Organizational } \\
\text { changes and } \\
\text { external } \\
\text { consultants }\end{array}$ & $\begin{array}{l}\text { Mize (1987); Tanakana (1991); Ferraro (1988); Co and Flowers } \\
\text { (1990); Beatty and Gordon (1988); Rosnah et al. (2005); } \\
\text { Yusuff (2004) }\end{array}$ \\
\hline 4 & $\begin{array}{l}\text { Continuing } \\
\text { management and } \\
\text { Manufacturing } \\
\text { support }\end{array}$ & $\begin{array}{l}\text { Efstathidas et al. (2002); Gupta (1998); Diaz (2003); Meredith } \\
\text { (1987a); Mize (1987); Salaheldin (2007) }\end{array}$ \\
\hline 5 & Human factors & $\begin{array}{l}\text { Mohanty (1993); Ferdows et al (1986); Voss (1986); Young and } \\
\text { Murray (1986); Weatherall (1988); Demmel and Askin (1992); } \\
\text { Troxler and Blank (1990); Sambasivarao and Deshmukh } \\
\text { (1994); Bessant (1991); Farley et al. (1987); Tchijov (1989); } \\
\text { Womack et al. (1991); Attaran 1992; Ettlie (1990); Diaz } \\
\text { (2003); Rosnah et al. (2005) }\end{array}$ \\
\hline 6 & $\begin{array}{l}\text { Vendor selection, } \\
\text { participation, and } \\
\text { continuity }\end{array}$ & $\begin{array}{l}\text { Sommers and Gupta (1991); Attaran (1989a, 1989b); Zahra } \\
\text { and Farzad (2010) }\end{array}$ \\
\hline 7 & $\begin{array}{l}\text { Implementation } \\
\text { practices }\end{array}$ & $\begin{array}{l}\text { Udoka and Nazemetz (1990); Chen and Small (1996); Chang } \\
\text { (1996); Hottenstein et al. (1997); Zhoa and Co (1997); Small } \\
\text { and Yasin (1997); Cleland et al. (1995); Beatty (1990); Beatty } \\
\text { and Gordon (1990); Bessant and Haywood (1988); Boer et al. } \\
\text { (1990); Nemetz and Fry (1988); Vesey (1990); Attaran (1992); } \\
\text { Billesbach (1991); Meredith (1987a, 1988); Ranta and Tchijov } \\
\text { (1990); Taheri (1990); Tchijov (1989); Doll and Vonderembse } \\
\text { (1987); Dornan (1987); Hershfield (1992); Meredith (1988); } \\
\text { Rubenowitz et al. (1990); Voss (1995); Rosnah et al. (2005); } \\
\text { Zahra and Farzad (2010) }\end{array}$ \\
\hline 8 & $\begin{array}{l}\text { Planning for } \\
\text { infrastructural } \\
\text { preparation }\end{array}$ & $\begin{array}{l}\text { Efstathidas et al. (2002); Beatty (1990); Meredith (1987a); } \\
\quad \text { Noori (1990); Dornan (1987); Jonsson (2000); Zammuto (1992) }\end{array}$ \\
\hline 9 & Social issues & Sambasivarao and Deshmukh (1994); Hershfield (1992) \\
\hline
\end{tabular}




\begin{tabular}{ccc}
\hline Number & Factor & Literature Relevance \\
\hline $\begin{array}{c}\text { Postimplementation phase } \\
10\end{array}$ & $\begin{array}{c}\text { Hands-on training } \\
\text { after installation } \\
\text { Setting of interim } \\
\text { targets }\end{array}$ & $\begin{array}{c}\text { Efstathidas et al. (2002); Udoka and Nazemetz (1990); Zahra } \\
\text { and Farzad (2010) } \\
\text { Efstathidas et al. (2002) }\end{array}$ \\
Performance \\
measurement & $\begin{array}{c}\text { Adler (1988); Brown and Laverick (1994); Ghalayini and Noble } \\
\text { (1996); Bititci et al. (2001); Karsak and Tolga (2001); Morgan }\end{array}$ \\
& and Daniels (2001); Kaplan and Norton (1992); Bititci et al. \\
& (1997); MacDougall and Pike (2003); Sohal (1991); Meredith \\
& (1988); Voss (1988); Primrose (1991); Small and Chen (1995); \\
& Finnie (1988); Attaran (1992); Curtis (1987); Kakati and Dhar \\
& (1991); Swamidass and Waller (1991); Wabalickis (1988); \\
& Meredith and Hill (1987); De Meyer and Ferdows (1990); \\
& Zahra and Farzad (2010) \\
& Diaz (1991); Chang (1989); Zahra and Farzad (2010) \\
\hline
\end{tabular}

[Appendices continue] 


\section{Appendix B}

\section{Constituent Factors}

\begin{tabular}{|c|c|}
\hline Constituent Factor & Literature Relevance \\
\hline Recognition of need & Small and Yasin (1997); Fry and Smith (1989) \\
\hline $\begin{array}{l}\text { Establishment of } \\
\text { organizational goals }\end{array}$ & $\begin{array}{l}\text { Chen and Small (1994); Falkner and Benhajla (1990); Small and Chen } \\
\text { (1995) }\end{array}$ \\
\hline $\begin{array}{l}\text { Linking business and } \\
\text { manufacturing strategies }\end{array}$ & $\begin{array}{l}\text { Anderson et al. (1989); Carlson et al. (1989); Cleland and Bursic (1992); } \\
\text { Udoka and Nazemetz (1990); Zahra and Covin (1993) }\end{array}$ \\
\hline Investment justification & $\begin{array}{l}\text { Swamidass and Waller (1991); Primrose (1991); Chen and Small (1996); } \\
\text { Diaz (2003); Attaran (1992); Curtis (1987); Dornan (1987); Kakati and } \\
\text { Dhar (1991); Wabalickis (1988); Amoako-Gyampah and Maffei (1989); } \\
\text { Attaran (1989); Meredith (1987a); Roth et al. (1991); Swann and O’Keefe } \\
\text { (1990a, 1990b) }\end{array}$ \\
\hline Operations strategy & $\begin{array}{l}\text { Boyer and MacDermott (1999); Miller and Roth (1994); Ward et al. (1998); } \\
\text { Parthasarthy and Sethi (1992); Corbett and Van Wassenhove (1993); } \\
\text { Kim and Lee (1993); Swink and Way (1995); Tranfield et al. (1991); } \\
\text { Anderson and Cleveland (1989); Cleland and Bursic (1992); Udoka and } \\
\text { Nazemetz (1990); Booz Allen and Hamilton (1982), Hayes, Wheelwright, } \\
\text { and Clark (1988); McDougall (1986), Cleveland (1986) }\end{array}$ \\
\hline Market position & $\begin{array}{l}\text { Sambasivarao and Deshmukh (1995); Blois (1986); Gupta (1988); Haskins } \\
\text { and Petitt (1988) }\end{array}$ \\
\hline Technology position & $\begin{array}{l}\text { Sambasivarao and Deshmukh (1995); Efstathidas et al. (2002); Roth and } \\
\text { Miller (1992); Miller and Roth (1994); Schroeder (1999); Dangayach and } \\
\text { Deshmukh (2005) }\end{array}$ \\
\hline $\begin{array}{l}\text { Long term automation } \\
\text { strategy }\end{array}$ & $\begin{array}{l}\text { Swamidass and Waller (1991); Blois (1986); Hershfield (1992); Dornan } \\
\text { (1987); Small and Yasin (1997); Hottinstein et al. (1997) }\end{array}$ \\
\hline Government policies & Sambasivarao and Deshmukh (1995) \\
\hline $\begin{array}{l}\text { Planning for human } \\
\text { resource development }\end{array}$ & $\begin{array}{l}\text { Efstathidas et al. (2002); Meredith (1981); Lewis (1998); Mcdermott } \\
\text { (1999); Parthasarthy (1992); Zoha and Co (1997); Zammuto (1992), } \\
\text { Dangayach and Deshmukh (2005) }\end{array}$ \\
\hline $\begin{array}{l}\text { Presence of formal } \\
\text { manufacturing strategy }\end{array}$ & Mize (1987) \\
\hline Availability & Sambasivarao and Deshmukh (1995), Sohal (1996) \\
\hline Flexibility & $\begin{array}{l}\text { Sohal (1996); Sambasivarao and Deshmukh (1995); Adler (1988); Dean } \\
\text { and Snell (1991, 1996); Gerwin (1993); Parthasarthy and Sethi (1993); } \\
\text { Swamidass and Kotha (1998); Kotha and Swamidass (2000), Rosnah et } \\
\text { al. (2005) }\end{array}$ \\
\hline Hardware and software & Sambasivarao and Deshmukh (1995) \\
\hline Productivity & Sohal (1996); Sambasivarao and Deshmukh (1995) \\
\hline Reliability & Sambasivarao and Deshmukh (1995) \\
\hline $\begin{array}{l}\text { Capability matching with } \\
\text { the operations strategy of }\end{array}$ & $\begin{array}{l}\text { Tetzlaff (1990); Udoka and Nazemetz (1990); Primrose (1991); } \\
\text { Sambasivarao and Deshmukh (1995); Kim and Lee (1993); Ramasesh }\end{array}$ \\
\hline
\end{tabular}




\begin{tabular}{|c|c|}
\hline Constituent Factor & Literature Relevance \\
\hline the firm & $\begin{array}{l}\text { and Jayakumar (1993); Boyer, 1998; Cagliano and Spina (2000); } \\
\text { Goldhar et al. (1991); Sohal (1996); Rosnah et al. (2005) }\end{array}$ \\
\hline $\begin{array}{l}\text { Compatibility with existing } \\
\text { systems }\end{array}$ & $\begin{array}{l}\text { Beatty and Gordon (1990); Stecke (1985); Tetzlaff (1990); McDonough and } \\
\text { Barczak (1992) }\end{array}$ \\
\hline $\begin{array}{l}\text { Programmed } \\
\text { implementation }\end{array}$ & Mize (1987) \\
\hline Need to reorganize & $\begin{array}{l}\text { Mize (1987); Tanakana (1991); Ferraro (1988); Co and Flowers (1990); } \\
\text { Beatty and Gordon (1988) }\end{array}$ \\
\hline $\begin{array}{l}\text { Need to revise policies and } \\
\text { procedures }\end{array}$ & $\begin{array}{l}\text { Mize (1987); Tanakana (1991); Ferraro (1988); Co and Flowers (1990); } \\
\text { Beatty and Gordon (1988) }\end{array}$ \\
\hline $\begin{array}{l}\text { Need for proper scheduling } \\
\text { of implementation process }\end{array}$ & $\begin{array}{l}\text { Mize (1987); Tanakana (1991); Ferraro (1988); Co and Flowers (1990); } \\
\text { Beatty and Gordon (1988) }\end{array}$ \\
\hline $\begin{array}{l}\text { Need for external } \\
\text { consultants }\end{array}$ & $\begin{array}{l}\text { Mize (1987); Tanakana (1991); Ferraro (1988); Co and Flowers (1990); } \\
\text { Beatty and Gordon (1988) }\end{array}$ \\
\hline $\begin{array}{l}\text { Top management explicitly } \\
\text { demonstrating support }\end{array}$ & $\begin{array}{l}\text { Efstathidas et al. (2002); Gupta (1996); Meredith and Hill (1987); Mize } \\
\text { (1987); Rosnah et al. (2005) }\end{array}$ \\
\hline $\begin{array}{l}\text { Top management willing to } \\
\text { Take risks }\end{array}$ & Diaz (2003); Meredith (1987a) \\
\hline $\begin{array}{l}\text { Top management providing } \\
\text { adequate financial support }\end{array}$ & $\begin{array}{l}\text { Efstathidas et al. (2002); Gupta (96); Meredith (1987a); Mize (1987); } \\
\text { Rosnah et al. (2005) }\end{array}$ \\
\hline Multiskilled employees & $\begin{array}{l}\text { Bessant (1991); Farley et al. (1987); Tchijov (1989); Womack et al. (1991); } \\
\text { Attaran, 1992; Ettlie (1990); Rosnah et al. (2005); Diaz (2003); Beatty } \\
\text { (1993); Hayes and Jaikumar (1991); Voss (1988) }\end{array}$ \\
\hline $\begin{array}{l}\text { Employee involvement and } \\
\text { motivation }\end{array}$ & $\begin{array}{l}\text { Attaran, 1992; Ettlie (1990); Tchijov (1989); Meredith (1987a); Voss } \\
\text { (1995); Chang and Lee (1996); Lewis and Boyer (2002); Gunasekaran et } \\
\text { al. (2001); Marri et al. (2007) }\end{array}$ \\
\hline Employee training & $\begin{array}{l}\text { Attaran (1992); Billesbach (1991); Meredith (1987a, 1988); Ranta and } \\
\text { Tchijov (1990); Taheri (1990); Tchijov (1989); Sohal (1994); Gerwin } \\
\text { (1988); Weill (1991); Adler (1986); Martin (1990), Dangayach (2005); } \\
\text { Rosnah et al. (2005) }\end{array}$ \\
\hline Employee relations & $\begin{array}{l}\text { Ferdows et al. (1986); Young and Murray (1986); Ghosh and Wabalickis } \\
\text { (1991); Sambasivarao and Deshmukh (1994); Collins and Hage (1988); } \\
\text { Diaz (2003), Gunasekaran et al. (2001); Marri et al. (2007) }\end{array}$ \\
\hline Emphasizing team work & $\begin{array}{l}\text { Beatty (1990); Beatty and Gordon (1990); Bessant and Haywood (1988); } \\
\text { Boer et al. (1990); Nemetz and Fry (1988); Vesey (1990); Diaz (2003); } \\
\text { Dean and Snell (1991); Boyer et al. (1997); Swamidass and Kotha (1998); } \\
\text { Rosnah et al. (2005) }\end{array}$ \\
\hline $\begin{array}{l}\text { Communicating the likely } \\
\text { impact of AMT to all } \\
\text { employees }\end{array}$ & Attaran (1992); Ettlie (1990); Tchijov (1989) \\
\hline $\begin{array}{l}\text { Selecting appropriate } \\
\text { vendors }\end{array}$ & Somers and Gupta (1991); Attaran (1989a, 1989b), Soh and Roberts (2005) \\
\hline $\begin{array}{l}\text { Maintaining close } \\
\text { relationship with vendors }\end{array}$ & Somers and Gupta (1991); Attaran (1989a, 1989b) \\
\hline Clear and long term amt & Hottenstein et al. (1997); Small and Yasin (1997); Udoka and Nazemetz \\
\hline
\end{tabular}




\begin{tabular}{lc}
\hline Constituent Factor & Literature Relevance \\
\hline objectives & $(1990)$ \\
Champion & Chen and Small (1996); Hottenstein et al. (1997); Zhoa and Co (1997); \\
& Beatty (1990); Boer et al. (1990); Meredith (1988); Rubenowitz et al. \\
& $(1990) ;$ Udoka and Nazemetz (1990) \\
Multidisciplinary planning & Beatty (1990); Doll and Vonderembse (1987); Dornan (1987); Hershfield \\
teams & (1992); Collins (1998); Rosnah et al. (2005); Small and Chen (1997); Voss \\
& (1988); Singh et al. (2007) \\
Multidisciplinary & Hershfield (1992); Beatty (1990); Boer et al. (1990); Meredith (1988); \\
installation teams & Rubenowitz et al. (1990); Hayes and Jaikumar (1991); Goldhar and \\
& Jelinek (1985); Collins et al. (1988); Gerwin (1988); Souder and \\
& Padmanabhan (1989); Hitt et al. (1993); Ettlie \& Reza (1992); Kahn \\
& (1996) \\
Special training for & Cleland et al. (1995); Udoka and Nazemetz (1990); Hottenstein et al. \\
implementation team & (1997); Sohal (1994); Lewis (2002) \\
Pilot projects & Zhoa and Co (1997); Udoka and Nazemetz (1990);.Lewis (2002) \\
Cost, quality, flexibility, & Adler (1988); Sohal (1991); Small and Chen (1995); Rosnah et al. (2005) \\
and time-based & \\
competition & \\
Technical success and & Udo et al. (1995) \\
business success & \\
Internal and external & Small and Yasin (1997) \\
performance measures & Udo et al. (1995); Sohal et al. (1999); Meredith (1988); Voss (1988); \\
Tangible and intangible & Primrose (1991); Small and Chen (1995) \\
factors & Ramamurthy (1995); Monge et al. (2006) \\
Operational and & \\
organizational & \\
performance &
\end{tabular}

[Appendices continue] 


\section{Appendix C}

\section{Working Definitions of the Constituent Factors}

\begin{tabular}{|c|c|}
\hline Factor & Definition \\
\hline Availability & $\begin{array}{l}\text { The technology in question is readily available or not? The } \\
\text { Necessary support from the vendor is available or not? }\end{array}$ \\
\hline $\begin{array}{l}\text { Capability matching with the } \\
\text { operations strategy of the firm }\end{array}$ & $\begin{array}{l}\text { Whether the system meets the operational requirements of } \\
\text { the plant? }\end{array}$ \\
\hline Champion & $\begin{array}{l}\text { Appointment of a technology champion (team leader) for } \\
\text { successful implementation of the technology }\end{array}$ \\
\hline $\begin{array}{l}\text { Clear and long-term AMT } \\
\text { objectives }\end{array}$ & $\begin{array}{l}\text { Setting up of well-defined management objectives about } \\
\text { what is expected from the technology }\end{array}$ \\
\hline $\begin{array}{l}\text { Compatibility with existing } \\
\text { systems }\end{array}$ & $\begin{array}{l}\text { Whether the system integrates well with the existing } \\
\text { equipment and also with future systems }\end{array}$ \\
\hline $\begin{array}{l}\text { Continuing management and } \\
\text { manufacturing support }\end{array}$ & $\begin{array}{l}\text { Top management explicitly demonstrating support, } \\
\text { continuing support from all other departments }\end{array}$ \\
\hline Emphasizing team work & The focus should be on team-work \\
\hline $\begin{array}{l}\text { Employee involvement and } \\
\text { motivation }\end{array}$ & $\begin{array}{l}\text { This is an indicator of active participation and cooperation of } \\
\text { employees in AMT projects }\end{array}$ \\
\hline Employee relations & $\begin{array}{l}\text { Emphasis placed by the company on employees job } \\
\text { satisfaction and safe working conditions }\end{array}$ \\
\hline Employee training & $\begin{array}{l}\text { Awareness of employees about new technology through } \\
\text { various training programs }\end{array}$ \\
\hline Establish organizational goals & $\begin{array}{l}\text { Need to establish organizational goals and performance } \\
\text { measures during the strategy formulation and planning } \\
\text { phase }\end{array}$ \\
\hline Flexibility & $\begin{array}{l}\text { Whether the system is flexible enough to accommodate the } \\
\text { design and manufacturing changes rapidly or not? }\end{array}$ \\
\hline Government policies & $\begin{array}{l}\text { Government policies play an important role in adopting and } \\
\text { implementing AMT }\end{array}$ \\
\hline $\begin{array}{l}\text { Hands-on training after } \\
\text { installation }\end{array}$ & $\begin{array}{l}\text { Training to the all concerned after installation of the } \\
\text { technology }\end{array}$ \\
\hline Hardware and Software & $\begin{array}{l}\text { This is the cost of necessary hardware, plant, equipment, } \\
\text { installations and software development as well as } \\
\text { installation costs }\end{array}$ \\
\hline Human resource management & $\begin{array}{l}\text { Human resource management may facilitate or hinder a } \\
\text { plant's ability to capitalize on the advantages of AMT }\end{array}$ \\
\hline Integrity of the AMT team & $\begin{array}{l}\text { The team should not be disband till the successful } \\
\text { completion of the project }\end{array}$ \\
\hline Investment justification & $\begin{array}{l}\text { Investment justification should include consideration of the } \\
\text { operational costs, strategic and operational benefits of } \\
\text { these systems }\end{array}$ \\
\hline $\begin{array}{l}\text { Linking business and } \\
\text { manufacturing strategies }\end{array}$ & $\begin{array}{l}\text { Need to link manufacturing strategy of the plant to business } \\
\text { strategy }\end{array}$ \\
\hline Long term automation strategy & $\begin{array}{l}\text { Automation strategy of a plant should be derived by } \\
\text { competitive priorities }\end{array}$ \\
\hline Market position & $\begin{array}{l}\text { Indicator of the competitive advantage, the price sensitivity, } \\
\text { the customer demand and the product mix }\end{array}$ \\
\hline Monitoring & $\begin{array}{l}\text { Continuous monitoring of the system for whether targets are } \\
\text { achieved or not? Corrective actions if not }\end{array}$ \\
\hline $\begin{array}{l}\text { Multidisciplinary installation } \\
\text { teams }\end{array}$ & $\begin{array}{l}\text { Indicator of installation team members from different } \\
\text { functional areas and departments }\end{array}$ \\
\hline
\end{tabular}




\begin{tabular}{ll}
\hline Multidisciplinary planning & $\begin{array}{l}\text { Formation of project teams from different functional areas } \\
\text { Multiskilled employees }\end{array}$ \\
& $\begin{array}{c}\text { This is an indicator of skill level of workers for operating } \\
\text { different machines }\end{array}$ \\
Need for external consultants & Help of external experts on systematic implementation \\
Need to reorganize & Infrastructural adjustment to support the new technology \\
Need to revise policies & Policy revisions needed to support the new technology \\
Operations strategy & AMT should be implemented in conjunction with a strategic \\
& emphasis on operations strategy of the plant \\
Performance measurement & Evaluation of the system \\
Pilot projects & Familiarization of the employees with the equipment, \\
& machinery and processes \\
Productivity & This is an indicator of the productivity of the system by \\
& reducing scrap, idle time and maximum utilization of men, \\
& machines, materials \\
Recognition of need & Recognizing the need to introduce new technology due to an \\
& increasingly complex and competitive, global and national \\
beliability & business environment \\
How often the system breaks down, mean time to failure \\
process
\end{tabular}

The International Journal of Applied Management and Technology (IJAMT), sponsored by Walden University's School of Management, is a peer-reviewed, online journal that addresses contemporary national and international issues related to management and technology. The objectives of the IJAMT are to: (a) encourage collaborative and multi-disciplinary examinations of important issues in business and technology management, and (B) engage scholars and scholar-practitioners in a dynamic and important dialogue.

Walden University Publishing: http://www.publishing.waldenu.edu 